\title{
PECULIARITIES OF ACTIVITY RENOVATION OF ZEOLITE CATALYSTS COKED IN HEXANE CRACKING
}

\author{
Lyubov Patrylak $^{1, *}$, Oleksandra Pertko ${ }^{1}$
}

https://doi.org/10.23939/chcht12.04.538

\begin{abstract}
The initial activity of acid zeolites in $n$-hexane cracking and influence of their regeneration depth on residual activity using the method of discrete-consecutive coke micro oxidation have been investigated. It was found that oxidation by $5-10$ pulses of oxygen properly reflects the activity of catalysts based on faujasite and pentasil, while for mordenite which has increased susceptibility to blocking of channels by coke, such quantity oxygen is not enough.
\end{abstract}

Keywords: cracking catalytic, zeolite acidic, activity, deposits carbon, regeneration.

\section{Introduction}

Catalytic cracking is known to be important largetonnage refining process that aims to increase the yield of gasoline products [1-4]. However, a catalyst in the hydrocarbon cracking deactivated extremely quick by carbonaceous deposits. As a result, it works only for a few seconds, and most time of its existence it resides in the regenerator. Therefore, the assessment of cracking catalyst deactivation features and restore of their activity during burning carbonaceous deposits is very important. A lot of studies are dedicated to the deactivation of zeolite catalysts [5-12]. However, in most of them scientists use flow reaction realization methods that does not provide adequate to industrial plant residence time of reagents on catalyst layer. For coke nature investigations a number of modern physical and chemical methods are used [13-16]. A method of discrete-consecutive coke micro oxidation (DCCMO) developed in the Institute of Bioorganic Chemistry and Petrochemistry $[17,18]$ allows, on the one hand, providing a minimum residence time of reactants and reaction products on the catalyst layer, and, on the other hand, burning carbonaceous deposits in the same reactor in situ by feeding of oxygen pulses.

The purpose of this study was to assess the impact of varying degrees of burning coke on residual activity of

\footnotetext{
${ }^{1}$ Institute of Bioorganic Chemistry and Petrochemistry of National Academy of Sciences of Ukraine

1, Murmans'ka St., 02660 Kyiv, Ukraine

*lkpg@ukr.net

(c) Patrylak L., Pertko O., 2018
}

acid catalysts based on zeolites of various types using micro pulse technique.

\section{Experimental}

Wide porous zeolite of faujasite type $(\mathrm{Y})$, the medium porous pentasil (ZSM-5) and a narrowly porous mordenite (M) were selected as the objects of this study. The first two are used as the base of modern cracking catalysts, and the third one - as a base of light gasoline fractions isomerization catalyst.

The samples investigated have been synthesized on the basis of powder zeolites $\mathrm{NaY}\left(\mathrm{SiO}_{2} / \mathrm{Al}_{2} \mathrm{O}_{3}=4.7\right)$, $\mathrm{NaM}\left(\mathrm{SiO}_{2} / \mathrm{Al}_{2} \mathrm{O}_{3}=9.8\right)$ and NaZSM-5 $\left(\mathrm{SiO}_{2} / \mathrm{Al}_{2} \mathrm{O}_{3}=41\right)$ produced by JS “Sorbent” (Nizhnij Novgorog, Russia).

Hydrogen forms of mordenite (HM) and pentasil (HZSM-5) were obtained by four-time ion exchange of native sodium cations by ammonium $\left(\mathrm{NH}_{4} \mathrm{NO}_{3}\right.$, $3 \mathrm{~mol} / \mathrm{dm}^{3}$ ) at $353 \mathrm{~K}$ for $2 \mathrm{~h}$ with intermediate calcination for $2 \mathrm{~h}$ at $823 \mathrm{~K}$. Solid/liquid phase ratio amounted to 1:2. The degree of exchange reached 97-99\%.

Sample HLaNaY was prepared by double exchange of native sodium cations by ammonium under the same conditions with intermediate calcination and single exchange on lanthanum from $1 \mathrm{~mol} / \mathrm{dm}^{3}$ solution of $\mathrm{La}\left(\mathrm{NO}_{3}\right)_{3} \cdot 6 \mathrm{H}_{2} \mathrm{O}$. Lanthanum content in the sample was $25 \%$ of the exchange capacity, residual sodium $-40 \%$.

Adsorption properties of synthesized samples are given in the Table.

Activity of fresh synthesized and regenerated samples was investigated in micropulse linear hexane cracking reaction.

Deactivation of catalysts and coke formed burning was performed using previously established combined DCCMO [17, 18] installation. Serial chromatograph "Tsvet-102" was equipped by a steel microreactor with polysilicon membrane at the top, through which the pulse dosing of hydrocarbon was performed in a stream of inert carrier gas (helium) and U-shaped trap in the bottom of the reactor for capturing of the reaction products. Quartz cover with grain size of $0.05-0.2 \mathrm{~mm}$ with a layer of the investigated catalyst $(0.1 \mathrm{~g}, 0.063-$ $0.1 \mathrm{~mm}$ fraction) by thickness of $1.5-2 \mathrm{~mm}$ is kept on the stainless steel reactor grid. 
Adsorption characteristics of the synthesized samples

\begin{tabular}{|l|c|c|c|}
\hline \multicolumn{1}{|c|}{ Characteristics } & \multicolumn{2}{c|}{ Sample } \\
\cline { 2 - 5 } & HLaNaY & HM & HZSM-5 \\
\hline BET surface area, $\mathrm{m}^{2} / \mathrm{g}$ & 936.37 & 444.8 & 361.2 \\
\hline BJH cumulative adsorption surface area of pores between 17 and 3000 $\AA, \mathrm{m}^{2} / \mathrm{g}$ & 54.9 & 53.6 & 47.3 \\
BJH cumulative desorption surface area of pores between 17 and 3000 $\AA, \mathrm{m}^{2} / \mathrm{g}$ & 73.2 & 78.9 & 62.6 \\
\hline Micropore area, $\mathrm{m}^{2} / \mathrm{g}$ & 842.3 & 366.0 & 275.1 \\
\hline Micropore volume, $\mathrm{cm}^{3} / \mathrm{g}$ & 0.374 & 0.162 & 0.122 \\
\hline
\end{tabular}

For analysis of cracking products a capillary column (diameter $0.2 \mathrm{~mm}$, length $50 \mathrm{~m}$ ) filled with squalane and a flame ionization detector were used. For separation of combustion products of carbonaceous deposits a packed column (diameter $3 \mathrm{~mm}$, length $2 \mathrm{~m}$ ) with a porous polymer "Polisorb-1" and a thermal conductivity detector were used.

The operating procedure for installation was as follows. A number of pulses of cracked hydrocarbon $(1 \mu \mathrm{l})$ have been dosed on the dehydrated sample by micro syringe. Cracking products after each pulse were caught in trap cooled with liquid nitrogen $(77 \mathrm{~K})$. After $10 \mathrm{~min}$ a dewar with liquid nitrogen was replaced by preheated portable oven, allowing to transfer trap content in the chromatographical column. After detection of all reaction products, the flow of helium was switched to another column and thermal conductivity detector. The trap was immersed in liquid nitrogen. Oxygen pulse $\left(1 \mathrm{~cm}^{3}\right)$ was submitted by syringe through the polysilicon membrane. After a short period of time on the chromatogram we can see a peak of oxygen rushed outside catalyst layer. After 15 min the dewar with liquid nitrogen under the trap was changed for preheated portable oven. As a result, the captured $\mathrm{CO}_{2}$ and $\mathrm{H}_{2} \mathrm{O}$ were fed to the column, separated and directed to the detector.

Deactivation of three portions of each sample was conducted by 7 pulses of $n$-hexane (at $773 \mathrm{~K}$ ). Such number of pulses provides residence time of the reactants on catalyst layer about 1-2 s, which is close to the industrial conditions of the catalyst work. Coke burning was provided by 5,10 , and 30 (35) pulses of oxygen. The maximum number of pulses 30 and 35 were selected based on previous studies [17, 19], because it provides the yield of burning curves on a horizontal line. After coke burning the samples were again tested in cracking of linear hexane.

\section{Results and Discussion}

The synthesized samples have significantly different activity (Figs. 1-3). HLaNaY has a relatively stable low conversion of $60 \%$ (Fig. 1). HZSM-5 and HM (Figs. 2, 3) show higher conversion of hexane (80-90\%) at first pulses. However, HM quite rapidly loses activity, apparently owing to the features of its porous structure - the presence of channels that can be blocked by coke deposits, limiting access to the acid sites in them. The relatively low initial activity of faujasite is caused by a low degree of ion exchange $(60 \%)$, which is not raised expressly with the purpose of sample deactivation by a small number of submitted hexane pulses.

Curves of coke burning (Fig. 4a) on HLaNaY for feeding 5 and 30 pulses of oxygen are descending, whereas in the experiment with 10 oxygen pulses several bursts of combustion (pulses 2 and 4) have been observed. Obviously in the points in front of them $\left(1^{\text {st }}\right.$ and $3^{\text {rd }}$ pulses $)$ the oxygen dose burns heavier coke, depleted by hydrogen, after burning of which at $2^{\text {nd }}$ and $4^{\text {th }}$ pulses the transition to richer hydrogen coke, which burns intensely, occurs.

Judging by the average $\mathrm{H} / \mathrm{C}(0.5-0.75)$ ratio, the vast majority of coke formed is presented by polyaromatics.

The total amount of coke burnt by 5, 10 and 30 oxygen pulses on faujasite was 251,310 and $394 \mathrm{mg}$, respectively. Assuming that 30 pulses burn almost all coke, $60 \%$ of coke is burned by feeding of five oxygen pulses.

For HM (Fig. 4b) a more or less uniformly decreasing burning is observed only in the experiment with 5 pulses of oxygen, whereas at 10 and 35 pulses of $\mathrm{O}_{2}$ bursts of combustion were observed. Moreover, their number and intensity are much greater than in the case of faujasite. These bursts can obviously be linked to disclosure of the channels of mordenite structure from carbonaceous deposits.

The range of $\mathrm{H} / \mathrm{C}$ ratios obtained for $\mathrm{HM}$ is significantly higher than for faujasite (0-1.2). In this case many points with practically zero hydrogen content have been observed. This fact confirms assumptions [19] about the possible formation of coke graphite-like on mordenite. But there are also values greater than one, which indicate that coke structure includes alkylsubstituted aromatics. Most of the points are still represented by polyaromatics with $\mathrm{H} / \mathrm{C}=0.5-0.8$.

The total number of coke burnt on HM was 185 , 338 and $752 \mathrm{mg}$ for 5,10 and 35 pulses of oxygen, respectively. It means that the coke burns much worse on mordenite than on faujasite, which is caused by the peculiarities of its porous structure: faujasite has input windows of $7 \AA$ and diameter of large cavities $13 \AA$, whereas larger mordenite channels have only $6.5 \times 7.0 \AA$, and smaller - 2.6×5.7 $\AA$. 


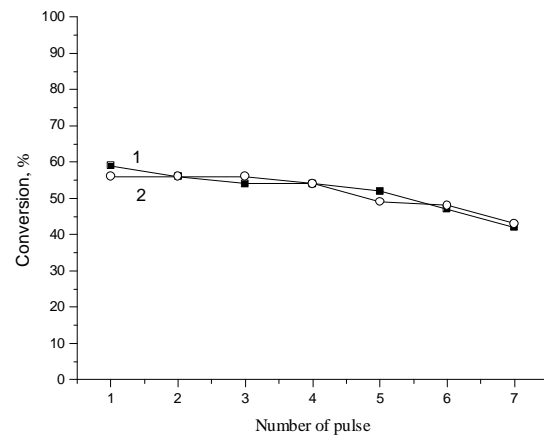

a)

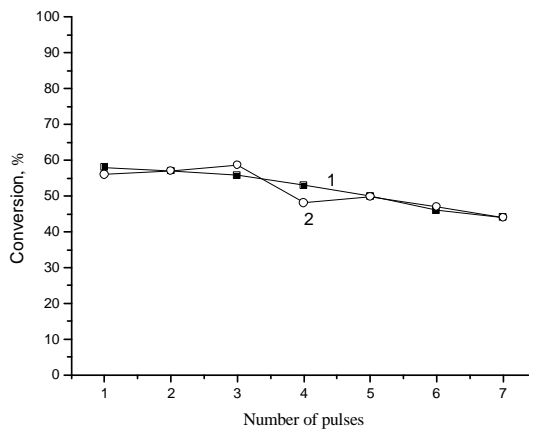

b)

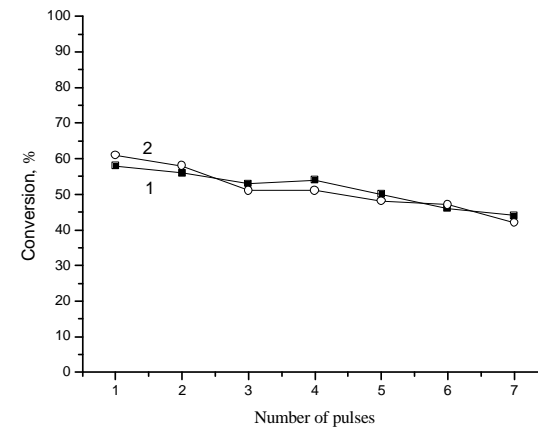

c)

Fig. 1. Initial (1) and residual (2) activity after regeneration of HLaNaY sample by 5 (a), 10 (b) and 30 (c) oxygen pulses

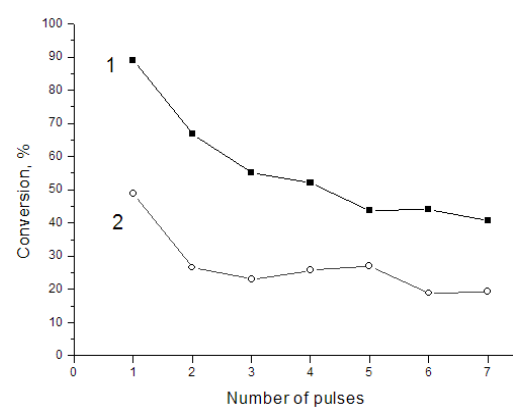

a)

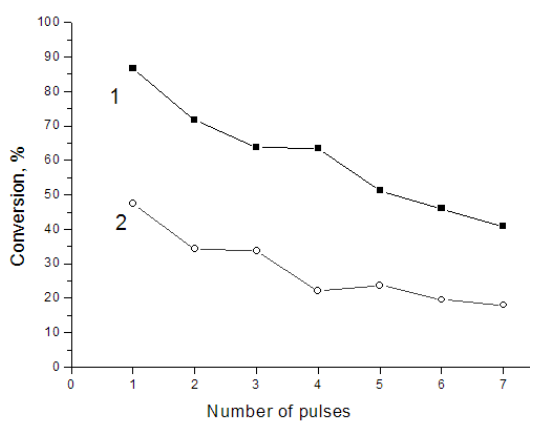

b)

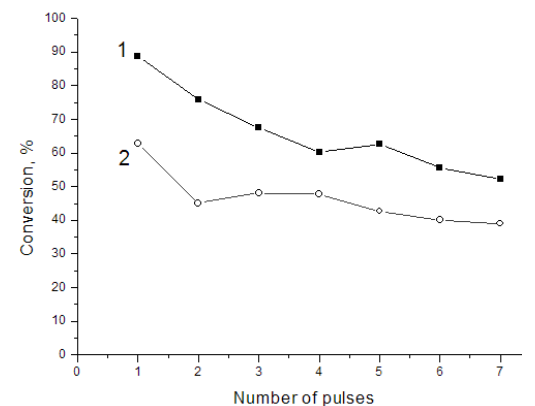

c)

Fig. 2. Initial (1) and residual (2) activity after regeneration of HM sample by 5 (a), 10 (b) and 35 (c) oxygen pulses

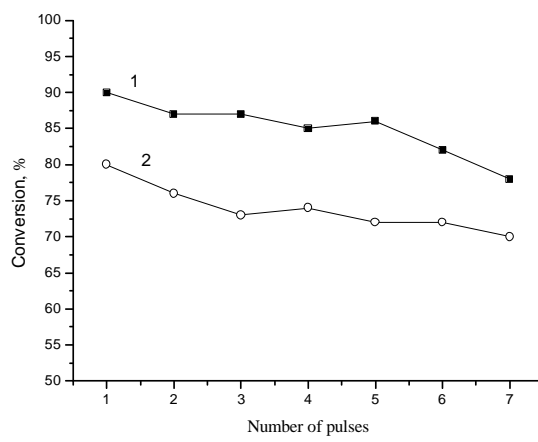

a)

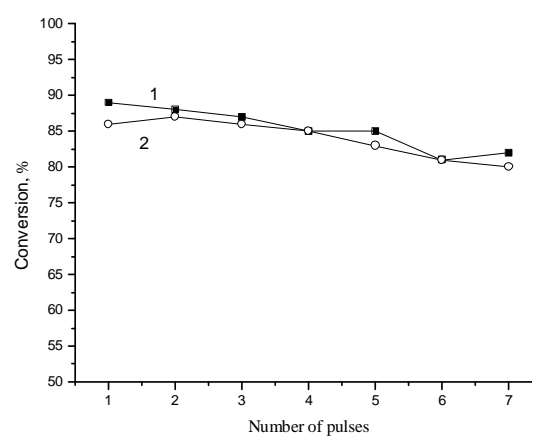

b)

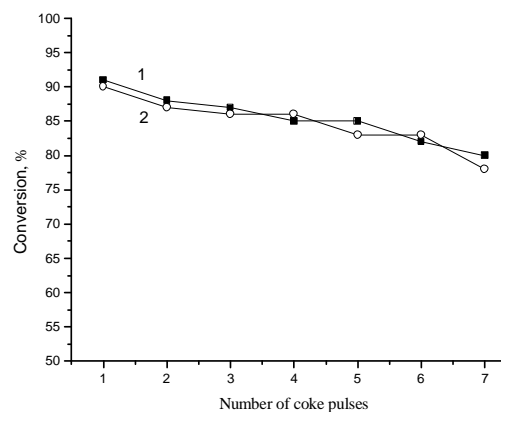

c)

Fig. 3. Initial (1) and residual (2) activity after regeneration of HZSM-5 sample by 5 (a), 10 (b) and 35 (c) oxygen pulses

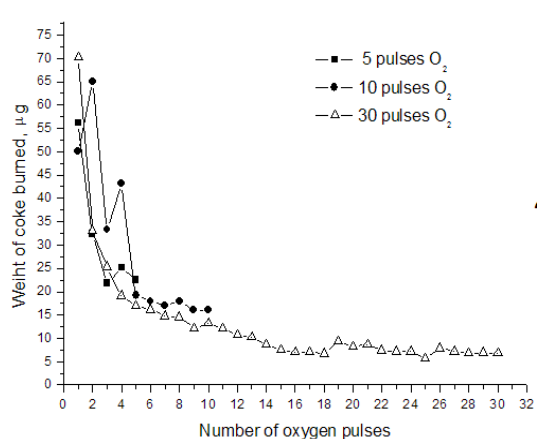

a)

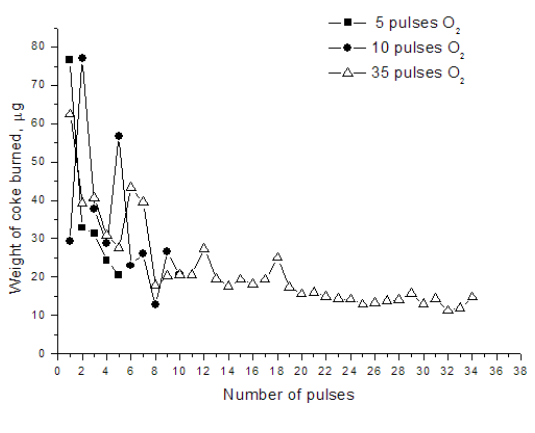

b)

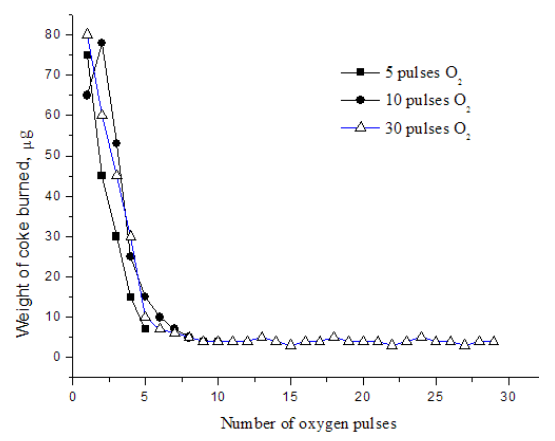

c)

Fig. 4. Dynamics of coke burning over HLaNaY (a), HM (b) and HZSM-5 (c) samples in dependence of the number of given oxygen impulses 
HSZM-5 (Fig. 4c) is characterized by decreasing, uniform burning of carbonaceous deposits in all three experiments. $\mathrm{H} / \mathrm{C}$ ratios correspond to polyaromatics (0.5-0.85). The total number of coke burnt on HSZM-5 is 180,266 and $327 \mathrm{mg}$ for 5, 10 and 30 pulses of oxygen, respectively.

Activity of HLaNaY is slightly changed after regeneration (Fig. 1). Regularities of initial and end conversion are mutually crossed. Burning of $60 \%$ coke by 5 pulses of oxygen allows to fully restore the sample activity.

There is a substantial (30-35\%) loss of activity for HM (Fig. 2) as a result of coke burning; the general character of curves is preserved.

A significant difference between the activity of the samples regenerated by 5 and 10 pulses of oxygen is not observed. The burning by 35 pulses of oxygen gives a noticeable increase in activity (by $10 \%$ ).

Activity of HZSM-5 (Fig. 3) is almost completely reproduced by 10 pulses of oxygen. Feeding of five oxygen pulses is not sufficient for proper access to the active centers. But coke burning from the pentasil sample is much better than that of the mordenite, despite the fact that it has a smaller surface of pore according to BET, a specific surface of micro- and mesopores, as well as the micropores volume (Table). The crossed pentasil channels provide better access of oxygen to carbonaceous deposits than parallel mordenite channels.

Thus, the DCCM method allows in situ estimation of the activity loss of the catalysts based on various types of zeolites during partial or complete regeneration.

Thus, the porous structure of the catalyst significantly affects the character of its activity in cracking of $n$-hexane, peculiarities of coke burning and recovery of activity after regeneration. Wide porous faujasite provides proper access of hydrocarbon molecules and oxygen to the acid sites and, despite the fact that the centers are weaker in strength (for hydrogen form of faujasite $H_{0}=(-13.7)-(-8.7)$, while mordenite $\left.H_{0}=(-11.3)-(-8.7)\right)$ [20], the sample better resumes activity relative to HM. Number of acidic sites in the HLaNaY and HM samples are theoretically close. Aluminum content in the faujasite is two times higher than in mordenite, but the sodium is replaced in this sample only by $60 \%$. So, the impact of varying amounts of acid centers is actually eliminated. The presence of lanthanum in faujasite sample also contributes to improvement of stability and smaller decrease in activity after regeneration. Mordenite, having a channel structure, is deactivated more quickly. If faujasite does not require complete regeneration, i.e. whole coke burning, the unblocking of mordenite sample pores requires more thorough burning of coke. Crossed channels of pentasil $(5.4 \times 5.6 \AA)$ also provide good access of oxygen for carbonaceous deposits burning, although more oxygen is required.

\section{Conclusions}

Using the method of discrete-consecutive coke micro oxidation, the activity of zeolite samples in cracking of linear hexane, and the depth of their impact on the regeneration of residual activity have been investigated. It was established that the activity of catalysts essentially depends on the availability of acid sites for reactive molecules, i.e. features a porous structure. Faujasite and pentasil demonstrate rather stable activity, while mordenite has an increased tendency to pores blocking by coke deposits. The presence of lanthanum in faujasite sample improves its stability in work and as a result, a smaller decrease in activity with time and after regeneration. It was found that oxidation by 5-10 oxygen pulses properly reflects the activity of the catalysts based on faujasite and pentasil.

\section{References}

[1] Wojciechowski B., Corma A.: Catalytic Cracking: Catalysis, Chemistry, and Kinetics. Marcel Dekker, Inc. New York 1986.

[2] Ocelli M., O'Connor P. (Eds.): Fluid Cracking Catalysts. Marcel Dekker, Inc. New York 1997.

[3] Nishimura Y.: Adv. Porous. Mater., 2017, 5, 17.

https://doi.org/10.1166/apm.2017.1120

[4] Corma A., Corresa E., Mathieu Y. et al.: Catal. Sci. Technol., 2017, 7, 12. https://doi.org/10.1039/C6CY01886F

[5] Groten W., Wojciechowski B.: J. Catal., 1990, 122, 362.

https://doi.org/10.1016/0021-9517(90)90290-Z

[6] Cerqueira H., Caeiro G., Costa L., Ramôa Ribeiro F.: J. Mol. Catal. A, 2008, 292, 1.

https://doi.org/10.1016/j.molcata.2008.06.014

[7] Cumming K., Wojciechowski B.: Sci. Eng., 1996, 38, 101. https://doi.org/10.1080/01614949608006455

[8] Den Hollander M., Makkee M., Moulijn J.: Catal. Today, 1998, 46, 27. https://doi.org/10.1016/S0920-5861(98)00348-4

[9] Patrylak L.: Adsorp. Sci. Technol., 2000, 18, 399.

https://doi.org/10.1260/0263617001493512

[10] Gusev A., Psarras A., Triantafyllidis K. et al.: Molecules, 2017, 22, 1784. https://doi.org/10.3390/molecules22101784

[11] Patrylak K., Patrylak L., Ivanenko V. et al.: Theoret. Exp. Chem., 2010, 46, 256. https://doi.org/10.1007/s11237-010-9149-7 [12] Argyle M., Bartholomew C.: Catalysts, 2015, 5, 145. https://doi.org/10.3390/catal5010145

[13] Guisnet M., Magnoux P.: Appl. Catal. A, 2001, 212, 83. https://doi.org/10.1016/S0926-860X(00)00845-0

[14] Bauer F., Karge H.: Mol. Sieves., 2007, 5, 249.

https://doi.org/10.1007/3829_005.

[15] Gil B., Mierzynska K., Szczerbinska M., Datka J.: Micropor.

Mesopor. Mater., 2007, 99, 328.

https://doi.org/10.1016/j.micromeso.2006.09.025 
[16] Vogt E., Weckhuysen B.: Chem. Soc. Rev., 2015, 44, 7342. https://doi.org/10.1039/C5CS00376H

[17] Ivanenko V., Voloshyna Yu., Okhrimenko M.: Theoret. Exp. Chem., 2009, 45, 198. https://doi.org/10.1007/s11237-009-9086-5 [18] Patrylak K., Patrylak L., Pertko O. et al.: Curr. Catal., 2016, 5, 108. https://doi.org/10.2174/2211544705666160322235846

[19] Okhrimenko M.: PhD thesis, Institute of Bioorganic Chemistry, Kyiv 2005.

[20] Umansky B., Hall W.: J. Catal., 1990, 124, 97. https://doi.org/10.1016/0021-9517(90)90106-T

\section{ОСОБЛИВОСТІ ВІДНОВЛЕННЯ АКТИВНОСТІ ЦЕОЛІТНИХ КАТАЛІЗАТОРІВ ЗАКОКСОВАНИХ В КРЕКІНЗІ ГЕКСАНУ}

Анотація. Методом дискретно-послідовного мікроокиснення коксу досліджено початкову активність кислотних цеолітів у крекінзі н-гексану та вплив ступеня регенерації на залишкову активність зразків. Знайдено, що окиснення 5-10 імпульсами кисню належним чином відновлюе активність каталізаторів на основі фожсазиту та пентасилу, тоді як для морденіту, який має підвищену схильність до блокування канальної структури коксом, такої кількості кисню не достатньо.

Ключові слова: крекінг каталітичний, цеоліти кислотні, карбонові відкладення, регенерація. 